EL DINAR: Jurnal Keuangan dan Perbankan Syariah

Volume 6, No. 2, Tahun 2018

P ISSN: 2339-2797; E ISSN: 2622-0083

\title{
DETERMINAN HOLDING PERIOD JAKARTA ISLAMIC INDEX
}

\author{
Nurul Fathani \\ Universitas Islam Negeri Maulana Malik Ibrahim Malang \\ nurullfathani@gmail.com \\ Ulfi Kartika Oktaviana \\ Universitas Islam Negeri Maulana Malik Ibrahim Malang \\ ulfiko@yahoo.com
}

\section{Abstract}

Market of financial capital is a good media to distribute the finance from the investors to the companies that need it. The investors give an investation to get a profit in the shape of capital gain or dividend. They can optimize the profit by deciding the golden time to buy or sell the investation. One of the ways to decide when the golden time comes is by looking at the holding period of the investation. A high holding period is showing a good condition of the investation because the investors will hold it when they get the profit optimally. That is also done in the contrary. This research is done to know the impact of market value, bid ask spread, and dividend payout ratio to the holding period. The samples of this research are all of the companies in Jakarta Islamic Index (JII) around 2014-2016 in sum thirteen in which the samples are taken by using purposive sampling. The data is a secular data that is got by the daily and annual report from the research object. Then, the data analysis process that is used is a regressive analysis of panel data with Eviews 9 program. The result of this research shows that, simultaneously, the variable of market value, bid ask spread, and dividend payout ratio is significantly influencing the holding period. Partially, the variable of dividend payout ratio has a positive influence to the holding period significantly, while for the variable of market value, variant return, and bid ask spread do not have a significant influence to the holding period.

Keywords: Market Value, Varian Return, Bid Ask Spread, Dividend Payout Ratio, Holding Period

\section{Abstrak}

Pasar modal menjadi media yang baik untuk menyalurkan dana dari para investor kepada perusahaan yang membutuhkan dana. Para investor melakukan investasi yang bertujuan untuk mendapatkan keuntungan berupa capital gain atau dividen. Investor dapat mengoptimalkan keuntungan dengan cara menganalisis kapan waktu yang tepat untuk 
membeli dan menjual investasi. Salah satu cara menentukan waktu yang tepat dengan melihat holding period dari investasi. Holding period yang tinggi menunjukkan keadaan investasi yang baik karena investor akan cenderung menahan investasinya ketika mendapat keuntungan yang optimal, begitu pula sebaliknya. Penelitian ini dilakukan untuk mengetahui pengaruh market value, bid ask spread, dan dividend payout ratio terhadap holding period. Jenis penelitian ini adalah kuantitatif. Sampel penelitian ini adalah perusahaan yang terdaftar dalam jakarta islamic index (JII) tahun 2014-2016 dengan jumlah sampel tiga belas perusahaan diperoleh melalui metode purposive sampling. Data yang diolah adalah data sekunder yang diperoleh peneliti melalui laporan harian dan tahunan dari objek penelitian. Proses analisis data yang digunakan adalah analisis regresi data panel dengan bantuan program Eviews 9. Hasil penelitian ini menunjukkan bahwa secara simultan variabel market value, bid ask spread, dan dividend payout ratio berpengaruh signifikan terhadap holding period. Secara parsial variabel dividend payout ratio berpengaruh positif signifikan terhadap holding period, sedangkan untuk variabel market value, varian return, dan bid ask spread tidak berpengaruh signifikan terhadap holding period.

Kata kunci: Market Value, Varian Return, Bid Ask Spread, Dividend Payout Ratio, Holding Period

\section{PENDAHULUAN}

Investasi menjadi suatu hal yang penting dilakukan dalam menjaga kestabilan keuangan dan meningkatkan kesejahteraan di masa yang akan datang. Masyarakat saat ini sudah mulai memikirkan pentingnya investasi. Menurut Thomas Trikasih selaku kepala Badan Koordinasi Penanaman Modal (BKPM) memapaparkan bahwa realisasi investasi pada tahun 2016 mengalami kenaikan sebesar 12,4 persen dibandingkan dengan tahun 2015 (Oktara, 2016), tidak hanya tahun 2015 ke tahun 2016 saja, tetapi sebelum tahun itu investasi juga selalu mengalami kenaikan. Dari angka tersebut sudah terlihat bahwa dari tahun ke tahun masyarakat sudah banyak yang melibatkan diri dalam dunia investasi.

Jenis sekuritas terbagi menjadi banyak jenis, akan tetapi saham merupakan sekuritas yang paling diminati karena mempunyai dua keuntungan yaitu capital gain dan dividen. Seorang investor memiliki kebebasan dalam memilih jenis saham yang dibeli, jumlah lembahr sahamnya, dan menentukan lamanya waktu memegang saham. Agar 
investor mendapatkan keuntungan yang optimal maka investor harus mengetahui waktu yang tepat untuk melakukan transaksi jual dan beli. Salah satu cara yang dapat dilakukan yaitu dengan melihat holding period. Holding period merupakan waktu yang diperlukan investor dalam memiliki saham yang dibelinya (Jones, 2000).

Holding period yang panjang menunjukkan keadaan saham yang baik karena investor yang cenderung menahan sahamnya maka dapat dikatakan investor tersebut mendapatkan keuntungan yang memadai, begitu pula sebaliknya. Dengan melihat nilai holding period maka investor akan mendapatkan gambaran umum dari keadaan saham tersebut. Jakarta Islamic Index (JII) merupakan indeks yang terdiri dari 30 emiten yang telah melalui tahap penyaringan syariah dan memiliki kapitaliasi pasar yang besar. Sehingga JII tempat yang bagus untuk dilkukan penelitian.

Tujuan dilakukannya penelitian ini adalah untuk mengetahui pengaruh market value, varian return, bid ask spread, dan dividend payout ratio terhadap holding period. Penelitian ini dilakukan di Jakarta Islamic Index (JII) dengan tahun penelitian 2014-2016.

\section{TINJAUAN PUSTAKA}

\section{Teori Signaling}

Menurut Fahmi dan Hadi (2009: 83), teori sinyal menjelaskan tentang keadaan harga di pasar yang mengalami kenaikan atau penurunan yang nantinya akan digunakan investor sebagai bahan pertimbangan pengambilan keputusan. Informasi apapun yang tercermin di pasar akan selalu dapat memberikan sinyal bagi investor dalam pengambilan tindakan untuk menyikapi informasi tersebut. Dalam melakukan investasi di pasar modal, keputusan investor dalam membeli atau menjual sekuritasnya cenderung didasarkan pada informasi-informasi yang dimiliki. Informasi tersebut dapat diperoleh dari informasi yang dipublikasikan oleh emiten maupun informasi pribadi. Lamanya seorang investor dalam menahan dana yang dimilikinya dapat dipengaruhi oleh adanya suatu informasi. 


\section{Pengertian Holding Period}

Holding period adalah banyaknya waktu yang diperlukan investor dalam penanaman dananya atas suatu sekuritas atau bisa dikatakan rata-rata waktu yang dibutuhkan investor untuk menahan saham yang dimiliki dalam kurun waktu tertentu. Waktu yang diperlukan investor untuk menahan saham yang semakin lama akan juga memperpanjang lamanya holding period saham tersebut, begitu pula sebaliknya (Jones, 2000). Rumus perhitungan holding period sebagai berikut (Atkins dan Dyl, 1997 dalam Arma 2013):

$$
\text { Holding Period }=\frac{\text { Jumlah Saham Beredar }}{\text { Volume Transaksi }}
$$

\section{Pengertian Market Value}

Menurut Horowitz (2000), market value adalah nilai pasar dari emiten yang dapat mencerminkan keadaan sebernarnya dari emiten tersebut. Nilai pasar dapat dihitung dengan cara mengalikan nilai pasar per lembar saham dengan jumlah saham yang beredar, dari perhitungan ini dapat dikatakan bahwa nilai perusahaan dapat ditentukan oleh pasar. Nilai market value dapat diperoleh dengan rumus (Atkins dan Dyl, 1997 dalam Arma 2013):

$$
M V_{i t}=\frac{\left[\sum_{t=1}^{N} \text { Harga saham }_{i t}\right]}{N} \times \text { jumlah saham beredar }{ }_{i t}
$$

\section{Pengertian Varian Return}

Menurut Arifin dan Tanzil (2008), variance of stock return adalah risiko total dalam suatu investasi saham yang diakitkan dengan expected return suatu emiten selama periode tertentu yang dinayatakn dalam bentuk persen. Besarnya varians ditentukan oleh pergerakan harga saham di pasar. Harga saham yang mengalami fluktuasi yang tinggi mencerminkan risiko yang tiggi juga. Berikut Rumus yang dipakai dalam penelitian ini:

$$
R S=\sqrt{\frac{\sum_{\mathrm{i}=1}^{\mathrm{n}}\left(\mathrm{X}_{\mathrm{i}}-\widetilde{\mathrm{X}}\right)^{2}}{\mathrm{n}-1}}
$$

\section{Pengertian Bid Ask Spread}

Menurut Jones (2000) Bid ask spread adalah selisih antara harga beli tertinggi atau bid price dengan harga jual terendah atau ask price 
Perbedaan dari kedua harga tersebut yang akan menjadi keuntungan bagi investor. Atkins dan Dyl (1997) dalam Arma 2013 menyatakan bahwa nilai bid ask spread dapat mencerminkan biaya yang dikeluarkan investor dalam melakukan transaksi jual maupun beli. Biaya transaksi adalah biaya yang terbentuk karena adanya transaksi jual beli saham seperti komisi, pajak, dan ongkos. Rumus perhitungan bid ask spread adalah (Atkins dan Dyl, 1997 dalam Arma, 2013):

$$
\text { Spread }_{\mathrm{it}}=\left[\sum_{\mathrm{t}=1}^{\mathrm{N}} \frac{\mathrm{Ask}_{\mathrm{it}}-\mathrm{Bid}_{\mathrm{It}}}{\left(\mathrm{Ask}_{\mathrm{it}}+\mathrm{Bid}_{\mathrm{it}}\right)_{2}}\right] / \mathrm{N}
$$

\section{Pengertian Dividend Payout Ratio}

Dividend payout ratio merupakan laba dari setiap lembar saham yang diinvestasikan pada suatu emiten yang akan dibagikan dalam setiap akhir periode investasi. Menurut Ermawati dan Margasari (2013), nilai dividend payout ratio akan mencerminkan kebijakan deviden suatu emiten yang nantinya akan berpengaruh terhadap keuntungan yang didapat investor dan juga akan mempengaruhi jangka waktu kepemilikan saham. Rumus yang digunakan untuk menghitung dividend payout ratio menurut Brigham dalam Atmaja 2008 dividend payout ratio dapat dihitung dengan rumus:

$$
D P R=\frac{\text { Dividend per share }}{\text { Earning per share }}
$$

\section{METODE PENELITIAN}

Jenis penelitian yang digunakan dalam penelitian ini adalah penelitian kuantitatif dengan pendekatan deskriptif pada perusahaan yang terdaftar dalam Jakarta Islamic Indeks (JII) tahun 2014-2016 dengan mengambil data sekunder yang dipublikasikan. Populasi dalam penelitian ini berjumlah 44 perusahaan dengan Sampel penelitian ini berjumlah 13 perusahaan yang diperoleh dengan cara purposive sampling. Analisis yang digunakan adalah analisis data panel dengan tahapan pemilihan model estimasi, pengujian asumsi klasik, pengujian signifikansi variabel kemudian iterpretasi hasil (Widarjono, 2009). 
Nurul Fathani: Determinan Holding Period

\section{HASIL ANALISIS}

Tabel 1. Uji Chow

\begin{tabular}{c|c|c}
\hline Effetc Test & Statistic & Prob. \\
\hline Cross-section F & 7.953 & 0.000 \\
\hline
\end{tabular}

Berdasarkan tabel diatas, nilai probabilitas $0.000<0.05$ maka model yang estimasi yang baik adalah Fixed Effect Model (FEM)

Tabel 2. Uji Hausman

\begin{tabular}{c|c|c}
\hline Test Summary & Chi-Square Statistic & Prob. \\
\hline Cross-section random & 4.503728 & 0.3421 \\
\hline
\end{tabular}

Hasil pengujian hausman menunjukkan nilai probabilitas sebesar $0.3421>0.05$ maka menggunakan Random Effect Model (REM).

\section{Uji LM (Lagrange Multiplier)}

$$
L M_{\text {hitung }}=\frac{13(3)}{2(3-1)}\left[\frac{3^{2}(6,036864)}{24,38158}-1\right]^{2}=14,712
$$

Hasil pengujian menunjukkan nilai $\mathrm{LM}_{\text {hitung }} 14,712>9,49$ nilai chi square tabel dengan variabel bebas sebanyak 4, maka dapat dinyatakan model yang terbaik adalah Random Effect Model (REM).

Berdasarkan ketiga pengujian, yaitu uji chow, uji hausman, dan uji LM yang telah dilakukan maka model yang tepat adalah untuk pengaruh market value (MV), varian return (VR), bid ask spread (BAS) dan dividend pay out ratio (DPR) terhadap holding period (HP) adalah Random Effect Model (REM) dengan persamaan model umum sebagai berikut: $H P=1.710+2.98 \times 10^{-15} M V-1.583 V R+58.561 B A S+0.899 D P R$

Tabel 3. Uji Normalitas

\begin{tabular}{c|c}
\hline Jarque Bera & 0.136 \\
\hline Probabilitas & 0.934 \\
\hline
\end{tabular}

Hasil di atas menunjukkan nilai Jarque Bera $0.136>0.05$ maka model regresi yang terbentuk dinyatakan terdistribusi normal.

Tabel 4. Uji Multikolinearitas

\begin{tabular}{c|c}
\hline Variabel & VIF \\
\hline Market Value & 1.237 \\
\hline Varian Return & 1.306 \\
\hline Bid ask Spread & 1.566 \\
\hline Dividend Pay Out Ratio & 1.068 \\
\hline
\end{tabular}


Berdasarkan output di atas, terlihat bahwa nilai VIF lebih kecil dari 10. Dengan demikian model regresi yang terbentuk tidak mengandung gejala multikolinier.

Tabel 5. Uji Heteroskedastisitas

\begin{tabular}{c|c}
\hline Obs*R-squared & 2.994 \\
\hline Probabilitas & 0.559 \\
\hline Hasil pengujian menunjukkan probabilitas $0.559>$ level of
\end{tabular}

significance (level $\alpha=5 \%$ ). Hal ini berarti residual memiliki ragam homogen. Dengan demikian asumsi heteroskedastisitas terpenuhi.

Tabel 6. Uji Autokorelasi

\begin{tabular}{c|c} 
Obs*R-squared & 9.946 \\
\hline Probabilitas & 0.077 \\
\hline Hasil di atas menunjukkan probabilitas $0.077>$ level of
\end{tabular}
significance (level $\alpha=5 \%$ ). Dengan demikian dapat dinyatakan bahwa antar observasi residual tidak saling berkorelasi, sehingga asumsi autokorelasi terpenuhi.

Tabel 7. Uji Determinan

\begin{tabular}{l|l}
\hline R-squared & 0.30 \\
\hline Sum squared resid & 25.42 \\
\hline
\end{tabular}

Hasil pengujian determinan menghasilkan nilai $R$-square sebesar 0.30. Hal ini menunjukkan keragaman holding period dapat dijelaskan oleh variabel independen sebesar 30\%, atau dengan kata lain kontribusi independen terhadap holding period sebesar 30\%, sedangkan sisanya sebesar 70\% merupakan kontribusi dari variabel lain yang tidak dibahas dalam penelitian ini.

Tabel 8. Uji Signifikan Simultan (Uji F-Statistik)

\begin{tabular}{c|c}
\hline Fstatistic & 2.932 \\
\hline Probabilitas & 0.035 \\
\hline
\end{tabular}

Pengujian hipotesis secara simultan menghasilkan nilai $\mathrm{F}_{\text {hitung }}=$ 2.932 dengan probabilitas 0.035 . Hasil pengujian tersebut menunjukkan probabilitas < level of significance $(\alpha=5 \%)$. Hal ini berarti terdapat pengaruh signifikan market value, varian return, bid ask spread dan dividend pay out ratio terhadap holding period. 
Nurul Fathani: Determinan Holding Period

\begin{tabular}{c|c|c|c|c}
\hline \multicolumn{6}{c}{ Tabel 9. Uji Signifikan Parsial (Uji t-Statistik) } \\
\hline Variabel & Koefisien & Std Error & Tstatistic & Prob \\
\hline Konstanta & 1.710 & 0.690 & 2.478 & 0.018 \\
\hline Market Value (X1) & $3.98 \mathrm{E}-15$ & $2.16 \mathrm{E}-15$ & 1.841 & 0.074 \\
\hline Varian Return (X2) & -1.583 & 1.199 & -1.319 & 0.195 \\
\hline Bid Ask Spread (X3) & 58.561 & 48.344 & 1.211 & 0.234 \\
\hline $\begin{array}{c}\text { Dividend Pay Out } \\
\text { Ratio (X4) }\end{array}$ & 0.899 & 0.372 & 2.415 & 0.021 \\
\hline
\end{tabular}

Berdasarkan hasil uji parsial diketahui nilai probababilitas market value (X1) $0.074>0.05$, varian return (X2) $0.195>0.05$, bid ask spread (X3) $0.234>0.05$ maka ketiga variabel tersebut memiliki pengaruh tidak signifikan tehadap holding period. Sedangkan variabel dividend payout ratio (X4) memiliki pengaruh signifikan karena nilai probabilitas $0.021<0.05$.

\section{PEMBAHASAN}

\section{Pengaruh Market Value terhadap Holding Period}

Hasil penelitian menunjukkan market value memiliki pengaruh positif tidak signifikan terhadap holing period. Nilai koefisien yang bernilai positif menunjukkan pengaruh market value terhadap holding period berbanding lurus. Nilai pasar yang baik menggambarkan keadaan perusahaan yang sedang baik, sehingga akan menyebabkan investor semakin lama memegang investasinya. Market value memiliki pengaruh tidak signifikan terhadap holding period disebabkan karena investor sekarang kebanyakan terlalu terobsesi dengan keuntungan yang didapat dari capital gain. Keuntungan dari capital gain diperoleh dari selisih harga beli dan harga jual saham. Perilaku investor yang demikian akan menyebabkan holding period akan menjadi semakin singkat karena investor akan segera menjual saham pada saat harga mulai naik tanpa memperhatikan market value perusahaan. Sehingga besar kecilnya nilai market value maka tidak akan mempengaruhi holding period.

\section{Pengaruh Varian Return terhadap Holding Period}

Hasil uji parsial yang menunjukkan bahwa varian return memiliki pengaruh yang negatif tidak signifikan terhadap holding period. Investasi di pasar modal memang memiliki risiko yang relatif tinggi. Kebanyakan 
orang yang melakukan investasi di pasar modal sudah menyiapkan berbagai hal untuk menyikapi risiko yang akan terjadi, salah satunya dengan menghindarinya ketika sudah dapat diramalkan risiko yang nantinya dialami akan sangat tinggi, hal ini dilakukan investor untuk meminimalisir kerugian yang akan terjadi. Perilaku investor yang memilih untuk mengahindari risiko tinggi akan menyebabkan menurunnya waktu penanaman dana investasi. Varian return tidak memiliki pengaruh yang signifikan terhadap holding period, karena saham-saham yang termasuk dalam Jakarta Islamic Index (JII) harus lulus berbagai syarat yang ditetapkan sebagai standar JII. Syarat-syarat tersebut tidak hanya mencakup segi keislamannya saja akan tetapi juga baik buruknya keadaan keuangan dari suatu perusahaan. Dengan adanya syarat-syarat tersebut dapat meminimalisisr risiko sehingga investor yang berinvestasi akan cenderung merasa aman dan tidak memiliki kekhawatiran terhadap risiko yang terjadi.

\section{Pengaruh Bid Ask Spread terhadap Holding Period}

Hasil penelitian menunjukkan bid ask spread memiliki pengaruh positif tidak signifikan terhadap holding period. Pengaruh bid ask spread terhadap holding period yang bernilai positif menunjukkan bahwa semakin tinggi bid ask spread, maka akan semakin lama pula masa holding period. Sebaliknya, ketika bid ask spread makin rendah maka masa holding period akan semakin singkat. Hal ini menunjukkan bahwa investor memperhatikan transaction cost dari setiap investasi yang dilakukan. Hasil penelitian yang menunjukkan bahwa bid ask spread tidak signifikan terhadap holding period disebabkan karena penelitian dilakukan pada negara berkembang seperti Indonesia, karena kebanyakan investor di Indonesia kepemilikan sahamnya terkonsentrasi pada perusahaan keluarga atau institusi, bukannya publik (Dwinanto (2010) dalam Dwi (2012: 56)). Namun, jika penelitian ini dilakukan di negara maju seperti pasar modal amerika, pasar modal jerman, pasar modal inggris, dan pasar modal di negara maju lainnya ada kemungkinan akan menghasilkan pengaruh signifikan karena kebanyakan struktur modal di pasar modal negara maju lebih didominasi oleh kepemilikan saham publik. 


\section{Pengaruh Dividend Payout Ratio terhadap Holding Period}

Hasil uji parsial menunjukkan dividend payout ratio memiliki pengaruh positif signifikan terhadap holding period. Hasil penelitian ini menunjukkan bahwa dividend payout ratio memiliki pengaruh yang signifikan dan searah dengan holding period. Seorang investor saham memiliki kesempatan memperoleh keuntungan dari investasinya berupa capital gain dan dividend. Dividend payout ratio merupakan gambaran kebijakan dividen dari suatu perusahaan yang akan mempengaruhi besarnya laba yang akan dibagikan per lembar saham yang diinvestasikan investor. Tingginya nilai dari devidend payout ratio dari suatu perusahaan akan membuat perusahaan tersebut membagikan deviden bagi para investor dengan nilai tinggi pula. Investor yang menerima dividen yang tinggi akan cenderung menahan sahamnya dengan harapan dapat terus menerus mendapatkan keuntungan yang tinggi dari investasinya. Hal inilah yang menyebabkan semakin besar dividend payout ratio maka akan menyebabkan semakin lama holding period.

\section{KESIMPULAN}

Berdasarkan hasil penelitian yang telah dilakukan maka dapat ditarik kesimpulan. Variabel market value (X1) memiliki pengaruh positif tidak signifikan terhadap holding period (Y). Variabel varian return (X2) memiliki pengaruh negatif tidak signifikan terhadap holding period (Y). Variabel bid ask spread (X3) memiliki pengaruh positif tidak signifikan terhadap holding period (Y). Variabel dividend payout ratio (X4) memiliki pengaruh positif signifikan terhadap holding period (Y).

\section{SARAN}

Investor yang akan melakukan investasi di pasar modal hendaknya memperlajari tentang pasar modal, penelitian ini dapat digunakan sebagi salah satu acuan untuk berinvestasi di pasar modal. Peneliti selanjutnya diharapkan dapat menambah variabel, tahun atau juga dapat memakai metode penelitian yang lain agar dapat memperoleh hasil penelitian yang lebih valid. 


\section{DAFTAR PUSTAKA}

Arifin, Agus Zainul., Tanzil, Tan Grace. (2008). Biaya Transaksi Periode Pemegangan Saham Biasa yang Terdaftar Di Bursa Efek Indonesia. Jurnal Siasat Bisnis. Vol 12 Nov 3. Pp 161-173.

Arma, Visita Yales. (2013). Pengaruh Bid-ask Spread, Market Value, dan Variance Return terhadap Holding Period pada Perusahaan yang tercatat di LQ-45, Skipsi (dipublikasikan). Sekolah Tingi Ilmu Ekonomi Perbanas. Surabaya.

Atmaja, Lukas Setia. (2008). Teori dan Praktik Manajemen Keuangan. Yogyakarta: CV ANDI OFFSET.

Dwi K, Andy. (2012). Analisis Pengaruh Spread, Market Value, Variance Return, dan Dividend Payout Ratio terhadap Holding Period pada Saham Perusahaan Go Public yang Tercatat dalam Index LQ45, Skripsi (dipublikasikan). Fakultas Ekonomi. Universitas Sebelas Maret. Surakarta.

Ermawati, Devita., Margasari, Naning. (2013). Pengaruh Bid Ask Spread, Dividend Payout Ratio, dan Market Value terhadap Holding Period Saham pada Perusahaan Manufaktur yang Terdaftar di Bursa Efek Indonesia Tahun 2011. Jurnal Manajemen Edisi 3.

Fahmi, Irham., Hadi, Yovi Lavianti. (2009). Teori Portofolio dan Analisis Investasi: Teori dan Tanya Jawab. Bandung: Alfabeta.

Horowitz A, S. H. (2000). Microganism and feed management in aquaculture. Global Aquaculture, The Advocate Vol 3. Issue 2, 3334.

Jones, C. P. (2000). Invesment Analysis and Management. Canada: John Wiley \& Sons Inc.

Oktara, Diko. (2016). BKM: Total Realisasi Investasi 2016 Rp 612,8 Triliun. Diperoleh tanggal 8 September 2017 dari https://m.tempo.co/read/news/2017/01/25/090839733/bkp mtotal-realisasi-investasi-2016-rp-612-8-triliun.

Widarjono, Agus. (2009). Ekonometrika Pengantar dan Aplikasinya. Yogyakarta: Ekonisia FE UII. 